Olga MARKÓ

Anett PANDURICS

\title{
3.4. ANALYSIS OF THE HUNGARIAN BUSINESS LIABILITY INSURANCE MARKET
}

\begin{abstract}
Summary
Safe, stable environment and predictability are of utmost importance during the operation of enterprises. One of the possible ways of preparing to the unexpected events and decreasing future risks is the insurance. Insurance companies offer several insurance products for companies, from which liability insurances are the most relevant. In the lack of insurance, uncommon damages that touch significant amounts may destroy companies and affect negatively even the economy. Insurances and liability insurances therefore have outstanding, stabiliser role. This stabiliser role has significant effect particularly during economic crises, as it contributes to the economic growth by providing safe environment background to the recovery. The aim of the study is to shed light on the role and significance of liability insurances, by presenting the individual products of liability insurance and the possible risks of the enterprises. Also to assess the development, tendencies and current state of liability insurance market by interviewing the main actors of the liability insurance market and by analysing the aggregated market data of the past 10 years. The study highlights the risks of the currently under-insured market and that of the enterprises that have chosen low insurance limits, and the necessity of the mutual cooperation between domestic entrepreneurs and the insurance market.
\end{abstract}

Keywords: Liability Insurance, Enterprise Risk Management, Economic Stability

\section{Introduction - types of the liability insurance}

The managements of enterprises (especially of SMEs) are often not aware of the special features and the content of the different types of liability insurance products available on the market. In order to clarify these issues, in the introductory part of this study our aim is to define and describe the special features of liabilty insurance services, as well as the types and content of the most important liability insurances.

Liability risks are defined as loss exposures or loss through legal liability arising from actions of businesses (and individuals) that cause harm to others (Illés and Megyeri, 2010). This risk is considered to be one of the key risks a company faces, and the type of risk varies greatly according to the type of the activity, the size and the legal environment of the specific company. Besides the typical noninsurance risk management techniques (such as risk avoidance, loss control, risk retention), liability insurance have proven to be an effective method to protect market players against liability losses. Liability insurance is a special construct, in which the insurance 
company covers the losses, damages causes by the insured (specifically the company or the manager of the company). The insurance company in this case covers the losses for which the insured is legally liable (Trieschmann et al., 2005).

The specificities of liability insurance differentiate it from other insurance lines, notably from the commercial property insurance. As you see in Table 1., these objective differences make the world of liability insurance more complex, the coverage is usually broader and the construct is loaded with much more uncertainty.

Table 1: Main differences between liablity and property insurance

\begin{tabular}{|c|c|c|}
\hline & Commercial liability insurance & $\begin{array}{c}\text { Commercial property } \\
\text { insurance }\end{array}$ \\
\hline $\begin{array}{l}\text { Trigger event } \\
\text { (when will the } \\
\text { insurance company } \\
\text { pay) }\end{array}$ & $\begin{array}{l}\text { All types of unlawful and harm } \\
\text { causing behavior committed by the } \\
\text { insured is a trigger event which is not } \\
\text { excluded in the contract (concerning } \\
\text { the subject to insurance coverage) }\end{array}$ & $\begin{array}{l}\text { Damage of assets defined in } \\
\text { the contract caused by } \\
\text { specific sorts of risk (in case } \\
\text { of the all risk coverage, the } \\
\text { 'not excluded' sort of risk) }\end{array}$ \\
\hline $\begin{array}{c}\text { Insured risk } \\
\text { (what will the } \\
\text { insurance company } \\
\text { pay) }\end{array}$ & $\begin{array}{l}\text { It reimburses damages caused by the } \\
\text { insured. It concerns insurance claims } \\
\text { related to injuries of properties and } \\
\text { persons based on liability insurance of } \\
\text { third persons. The competence of the } \\
\text { insurance is often not well-defined. } \\
\text { Reason: human activity }\end{array}$ & $\begin{array}{c}\text { Reimbursement of damages } \\
\text { arisen in the insured property } \\
\text { and only in case of property } \\
\text { damages } \\
\text { For natural reasons and/or } \\
\text { human activity }\end{array}$ \\
\hline $\begin{array}{l}\text { Size of claim } \\
\text { (what is the amout } \\
\text { the insurance } \\
\text { company will pay) }\end{array}$ & $\begin{array}{l}\text { Maximum limit of compensation for } \\
\text { the insurance company is the limit } \\
\text { laid down in the insurance contract } \\
\text { (but the actual damage as a } \\
\text { maximum); costs of the legal } \\
\text { representation have to be covered by } \\
\text { the insurance company additionally. }\end{array}$ & $\begin{array}{l}\text { The compensation is limited } \\
\text { by the limits laid down in the } \\
\text { insurance contract and by the } \\
\text { value of the insured } \\
\text { properties. The size of claim } \\
\text { is equal to the amount of the } \\
\text { insurance, but to the value of } \\
\text { the damage as a maximum. }\end{array}$ \\
\hline $\begin{array}{l}\text { Time between } \\
\text { premium } \\
\text { payment and } \\
\text { claims settlement } \\
\text { (from what time } \\
\text { the insurance } \\
\text { company will pay) }\end{array}$ & $\begin{array}{l}\text { Longer duration of proceeding. } \\
\text { Revelation of the damage may be } \\
\text { delayed, the payment of the } \\
\text { compensation and the establishment } \\
\text { of the liability may take longer period. }\end{array}$ & $\begin{array}{l}\text { In general there is no/slight } \\
\text { delay. Claim settlement is } \\
\text { relatively fast. }\end{array}$ \\
\hline
\end{tabular}

Source: based on Swiss Re (2014), page 2.

Liability losses are more difficult to be estimated than property insurances as trigger events causing liability for compensation cannot be seen in advance. Furthermore, there is no such exact amount as that of the value of the insured properties, which could help the calculation of the maximum insurance amount. What is also an important difference and differentiating liability insurances from other sectors, is that the damage is not independent from the insured, as coverage concerns the damages 
caused by the insured himself. In this case, it is only the insured person and his activity which helps the insurance company, but not the contracted amount (e.g.in case of casco insurance, it is the value of the car which helps the calculation). Dealing with information asymmetry and moral hazard and creating the structure of incentives are amongst the responsibilities of the insurance company.

On the other hand, the volume of damages (and the willingness of validating the insurance claim) largely depends on the legal and political environment. Nagy and Micski (2012) emphasizes that one can experience change in the attitude towards compensation which is influenced by the change in consciousness of the consumers, by the case-law concerning compensation, by the publicity of information and by the activeness of the advocates. These factors affect essentially the activeness of the customer regarding the validation of the insurance claim.

Furthermore, the duration of proceeding of the claim settlement takes longer time in general (it might take years or even decades to close a damage). Within this procedure, the occurrence of the insurance claim and reporting on the damage (whether for objective reasons or not) might already suffer significant delay (even after the termination of the contract). When a more difficult insurance claim concerning also a bigger amount incurres, there is also bigger possibility that the settlement requires longer and more intense legal procedure supported by legal experts, since establishing the liability and defining the amount is indeed a complex question in many cases (especially in case of damages causing personal injuries and spill-over effect). Liability insurances are called classic long-tail modes by the litterature which means the division of damage in such a way that lots of small damages occur on the one hand, but there are some significant damages on the other hand, therefore the division's tail is very long. In case of the liability insurances, the percentage of the not yet reported damages is also bigger than that of the damages incurred, since there might be a longer time-gap between causing the damage and reporting on it (e.g.when a trigger event occur due to medical malpractice or legal error, but it has only been revealed later). In these cases a higher IBNR- reserve might be required. (Pandurics and Markó, 2015) The tipology of the classic commercial liability insurances and professional liability insurance offered on the market is presented in Table 2.

Table 2: Types of commercial liabilty insurances

\begin{tabular}{|l|}
\hline Commercial general liability (CGL) \\
\hline Excess liability, umbrella \\
\hline Environmental impairment liability \\
\hline Product liability, Product recall and product integrity \\
\hline Workers compensation and employers' liability, employment practices liability \\
\hline Directors and Officers insurance (D\&O) \\
\hline $\begin{array}{l}\text { Professional liability or errors and omission (such as medical malpractice or cover for } \\
\text { accounting firms, layers, architects, etc.) }\end{array}$ \\
\hline
\end{tabular}

Source: based on Swiss Re (2009) p.7-8 and Swiss Re (2014) p.32. 
The commercial general liability (CGL) used by companies to cover their general liability loss exposures. In the framework of a general liability insurance contract the insurance company covers those damages of persons and outside of the contract those property damages for which the entrepreneur or the company is liable in compliance with their compensation responsibilities laid down in the contract (Illés and Márki, 2000. Damage caused outside of the contract means that while undertaking the insured or related activity the insured entrepreneur or company cause damage regarding the activity defined in the insurance contract for a person with whom they are not in contractual relationship, or who is not user of the service provided by the insured entrepreneur or company.

This liability policy covers bodily injury, property damage, personal and advertising injury and medical payments. The insurance company agree to pay on behalf of the insured except the damage is expected or intended. Among oher things ,contractual liability, liquor liability, workes compensations, employers liability, environment pollution and aircraft are also in the exclusion list. As catastrophic loss exposures are not covered by commercial general liabilty, an excess or umbrella liability can help and provide protection to the business firms.

The excess liability insurance is the insurance coverage completing the compensation limit of the basic insurance, meanwhile the umbrella insurance is the insurance coverage completing the basic insurance which may concern both the limit and the risk. The environmental impairment liability insurance is a less known type of insurances even though environmental protection issues have reached central point on the agendas recently. In Hungary, concluding such an insurance by the person producing bigger quantity of waste, its recipient, the supplier, the storage and the handling companies, is prescribed by law.

In addition, it is worth considering this construction in all cases when a group endanger its environment as restoration of damages might cost a fortune. In addition, there are product or service provider liability insurances as well on the market, which cover non-professional insurance claims caused in the framework of the contractual relationship. For the employees, it is of utmost importance to have an employers' liability insurance which provides financial support when the employee (or anyone to whom the employer causes damage with personal injury) suffers work accident and claims compensation in relation to this from the employer.

Directors and Officers liability insurance $(\mathrm{D} \& O)$ protect managers from claims which may arise from their own activities and own decisions. These activities and decisions are out of the company's contractual relationaship and not in connection with the company's operations and goals. Professional liability insurance offers liability covers for special professional risks. This types of insurance provides protection to professionals such as lawyers, brokers, accountants, physicians, pharmacologists ect., whos cause damage to a third person under performing their professional services. These third persons are in contractual relationship with the professionals (Rejda and McNamara, 2014). 


\section{Analysis of the Hungarian business liability market}

The presentation of the assessment of changes and tendencies occurred on the liability insurance market and the presentation of the role and significance of the corporate liability insurances were amongst our research goals. While concluding our analyses, we reviewed the current literature regarding the topic, assessed the aggregated market data provided by the MABISZ and interviewed the main actors of the liability insurance market.

The Hungarian liability insurance market is underdeveloped; the insurance penetration is significantly lower than the world average. As it is shown on Table 3., the largest market is by far the liability market of the United States, where $0,5 \%$ of the total GDP was spent on liability insurance in 2013. In Hungary, the same ratio was only $0,06 \%$, which shows that the Hungarian companies have not yet realized the importance and significance of liability insurance as a risk management technique. As recent (2010) tragic event in Hungary has proven, some already paid a high price for that (the largest industrial disaster: waste reservoir collapsed at MAL Co. (covered up to 10 million HUF limit with liability insurance) released hazardous red sludge killing 10 people and causing at least 39 billion HUF in overall damages (hvg.hu).

Table 3: Liability insurance penetration in international comparison

\begin{tabular}{|c|c|c|c|c|c|c|}
\hline \multirow[b]{2}{*}{ Rank } & & \multicolumn{3}{|c|}{$\begin{array}{c}\text { Premiums \& GDP (USD billions) } \\
-2013 \\
\end{array}$} & \multicolumn{2}{|c|}{ Percentage share } \\
\hline & & Liability & Total Non-Life & GDP & $\begin{array}{l}\text { Liability/Total } \\
\text { Non-Life }\end{array}$ & Liability/GDP \\
\hline 1 & US & 84 & 531,2 & 16802 & $15,8 \%$ & $\mathbf{0 , 5 0} \%$ \\
\hline 2 & UK & 9,9 & 99,2 & 2521 & $10,0 \%$ & $0,39 \%$ \\
\hline 3 & Germany & 7,8 & 90,4 & 3713 & $8,6 \%$ & $0,21 \%$ \\
\hline 4 & France & 6,8 & 83,1 & 2750 & $8,2 \%$ & $0,25 \%$ \\
\hline 5 & Japan & 6 & 81 & 4964 & $7,4 \%$ & $0,12 \%$ \\
\hline 6 & Canada & 5,2 & 50,5 & 1823 & $10,3 \%$ & $0,29 \%$ \\
\hline 7 & Italy & 5 & 47,6 & 2073 & $10,5 \%$ & $0,24 \%$ \\
\hline 8 & Australia & 4,8 & 32,7 & 1506 & $14,7 \%$ & $0,32 \%$ \\
\hline 9 & China & 3,5 & 105,5 & 9345 & $3,3 \%$ & $0,04 \%$ \\
\hline 10 & Spain & 2,2 & 31 & 1361 & $7,1 \%$ & $0,16 \%$ \\
\hline & TOP10 & 135 & 1150 & 46900 & $11,7 \%$ & $0,29 \%$ \\
\hline & World & 160 & 1550 & 61700 & $10,3 \%$ & $0,26 \%$ \\
\hline & Hungary & 0,067 & 1,3042 & 105 & $5,1 \%$ & $0,06 \%$ \\
\hline
\end{tabular}

Source: Swiss Re (2014), p5.

The Hungarian insurance market has been steadily growing from a very low base level (see Figure 1.). In 2014 the total liability insurance market amounted up to ca. 20 billion HUF gross written premium. The claim ratio has only been $23 \%$ on average in 
the last 10 years (2005-2014), signaling a market segment with above average profitability compared to the total non-life insurance market profitability.

Figure 1: Development of the Hungarian liability insurance market 1998-2014

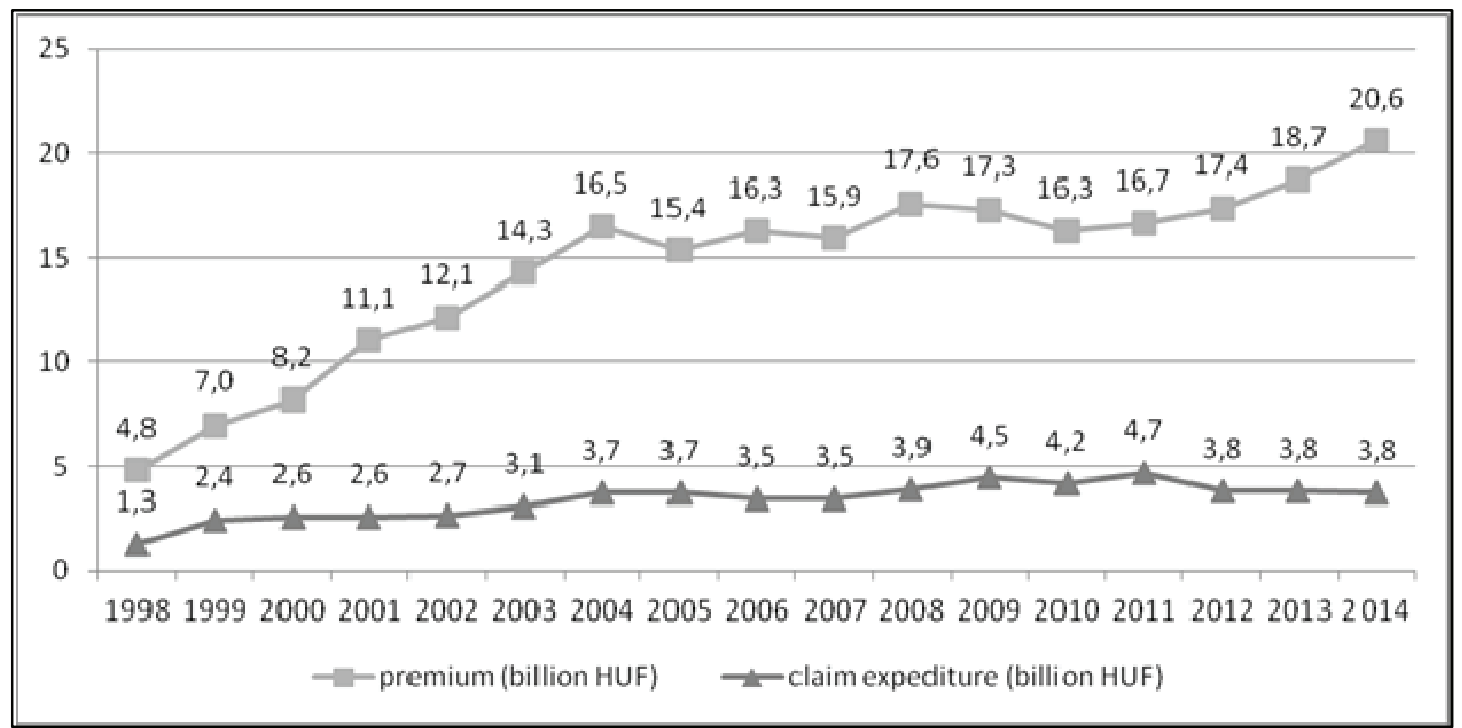

Source: MNB (2015)

In 2014 , the small segment ( $8,8 \%$ of the liablity insurance market) of Directors \& Officers Liability Insurance (D\&O) has received more attention and focus due to significant changes in the Hungarian Civil Code, according to which from March 15, 2014, companies and the management of companies are universially liable for damages caused by the company. As a result, D\&O insurance grew significantly: closing portfolio was 615 million HUF in 2013 vs.1.819 million HUF in 2014. The number of contracts is still very low (only 3811). Despite of the low number of contracts $(3,7 \%$ of the liablity insurance market), the increasing of premium of D\&O insurances (1204 million) on the whole liability insurance market means almost $30 \%$ of the 4 billion increase which took place in the past year. Figure 2. shows the total premium and ratio of the three main types of the liability insurance in 2013 and 2014.

The growth of the total premium can be explained partly by the increasing number of contracts (professional and $\mathrm{D \& O}$ ) and partly by the increasing of general premiums. The degree of being exempted from responsibility during professional damages decreases which shows to the direction of the objective responsibility.

Regulations make compulsory to conclude liability insurance in case of an increasing number of professions which draw the market's attention to the liability insurances. Besides, the insurance amounts of HUF 5-10 million laid down in the contracts concluded by the domestic companies deemed to be rather low. This is partly due to the bounding nature of insurances, as companies cannot see the real significance of the insurance, their primary goal is to conclude the contract on the lowest price possible. The management of most of the companies is not able to seize correctly the risks and 
their degree which the company has to face which also leads to the consequence that the chosen liability insurance does not cover the possible risks.

Figure 2: Premium of the Hungarian liability insurance market

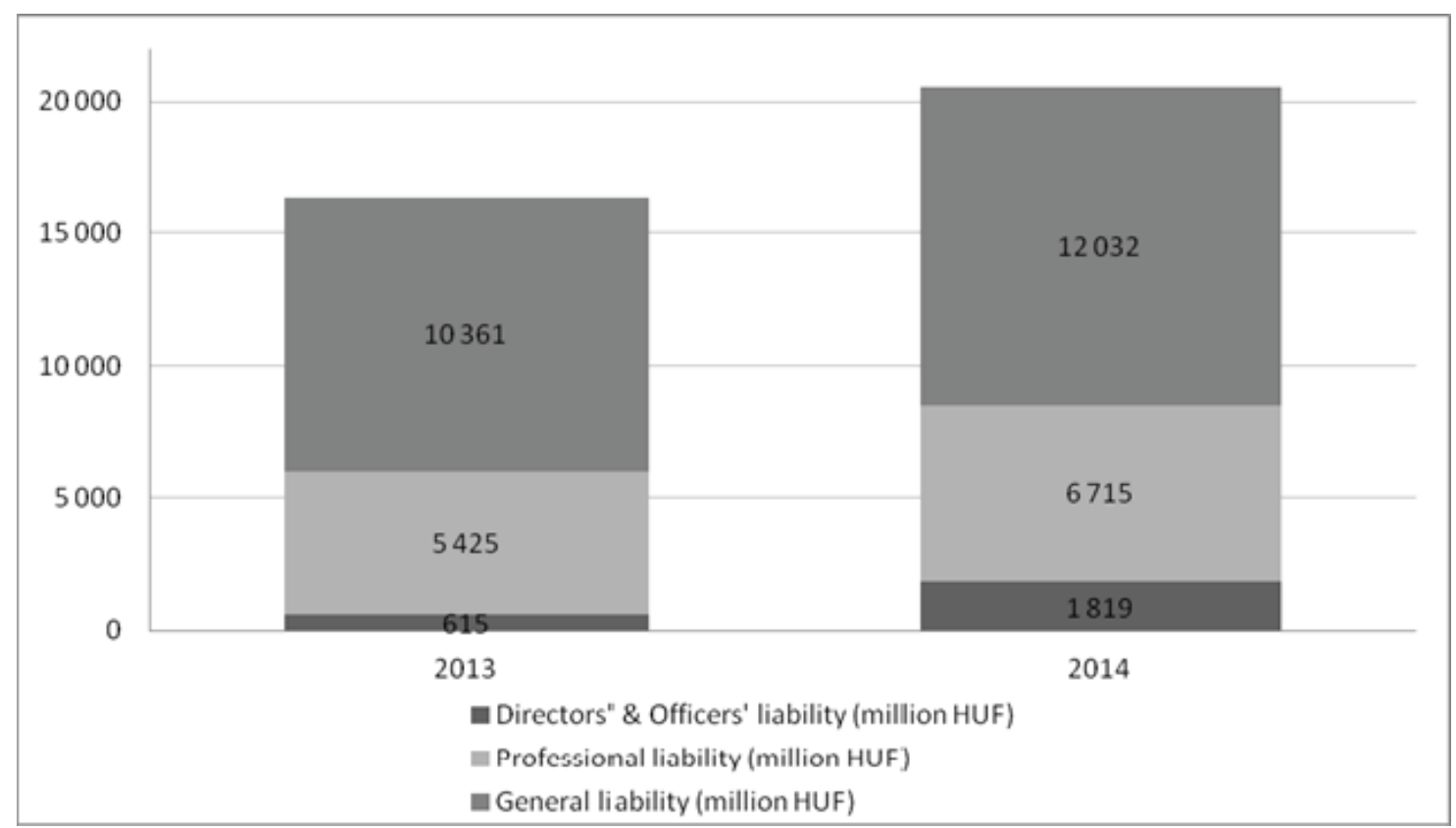

Source: MABISZ (2015)

Besides the compulsory liability insurance contracts, there are more professional areas where the compulsory liability insurance limit is still missing (that is there is no minimum insurance amount). Consequently, a contract concluded with a minimal limit may be satisfactory to be in compliance with the liabilities laid down in the law for the representatives of several areas, such as the veterinarinarians (Act CXXVII. of 2012), health service providers, leaders of medical researches (Act CLIV. of 1997), hunters (Act LV. of 1996) or operators of a firing range (MoI Regulation No.49/2004. VIII.31.).

However the minimum insurance amounts defined by the law raise also problems, lawyers are obliged to pay HUF 8 million per insurance claim and 16 million per year as a total limit which cannot be deemed realistic in comparison with the extent of the possible risk (Bylaw of the Hungarian Bar Association No.7/2011. X.24).

The Hungarian liability insurance market may be considered strongly concentrated that can be seen in Figure 3. The summary has been prepared based on the data of the year 2014 which contains not only the general liability insurance but the professional and the D\&O insurances as well. 
Figure 3: Trends in the Hungarian liability insurance market

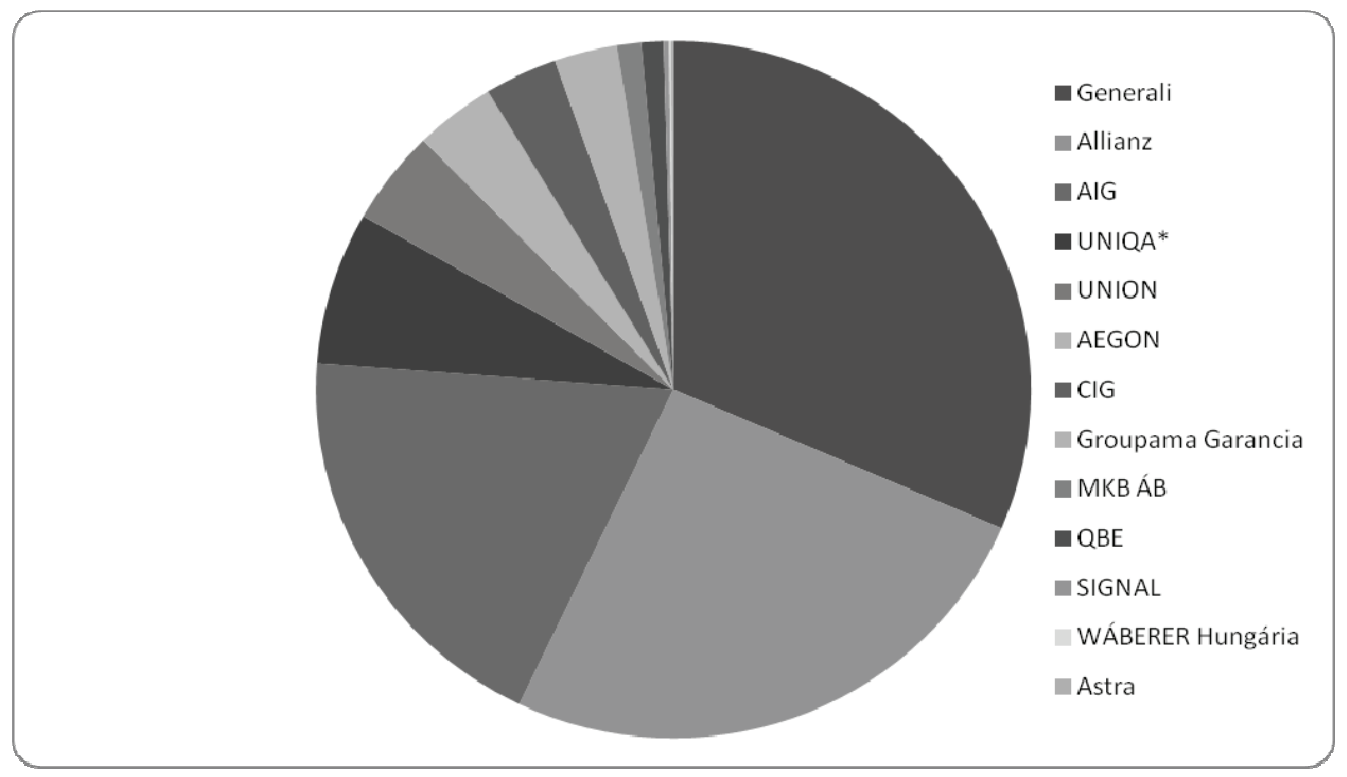

Source: MABISZ 2014. IV. quarter

Generali has the biggest share of the market $(31,51 \%)$ and the two biggest insurance company covers $57,1 \%$ of the market. AIG also has a significant share $(19,1 \%)$, which means $76,2 \%$ share altogether for the three biggest company. Amongst the 13 companies, there are only 6 which offers D\&O insurance, while 11 companies offers professional insurance and general liability insurance is available at all the 13 companies. Since the D\&O insurances were given more attention only in 2014, in the future it is expected to be included of the portfolios of other companies as well.

One can see similar strong concentration if only the professional liability insurance market is examined, where the market share of the three biggest company (Allianz, Generali, Chartis) is $71,6 \%$ regarding the data of 2010 based on the study of Kovács and Nagy (2011). They defined the relatively low manpower of the professional risk pool as the reason of the high market concentration.

\section{Conclusions}

Although in the past year the modification of the legal background contributed to the increasing role of the liability insurance, the domestic enterprises are still not fully aware of their significance. One of the biggest problems of the domestic market is the extremely low penetration. Having an insurance is not sufficient in itself if it does not cover the real risks or does not provide the appropriate cover on the given risk.

This is also the case at the professional liability insurances - prescribed by law - where there is no obligatory limit defined. In these cases, the coverage is not convenient if the representative of the given profession concludes the insurance only due to its 
obligatory nature and not because he feels threatened indeed. This also means that the limit defined freely is much lower than the real risk.

Professional organizations have to reach (push) the increase of limits prescribed by law to a rational level and in certain cases specifying the obligatory limits. Otherwise, the concluded liability insurance does not meet with its original function, that is it does not protect the insured from real risks.

To decrease the lack of information on corporate side, experts should also be involved. Regarding real risks seized by these experts, the insurances concluded on appropriate limits (even HUF 50-100 million) may provide real cover for the companies.

Liability insurance penetration will certainly show an increase in the future, since we expect the continuous spreading of configurations of objective liability also in Hungary. Supported also by more rigorous legal background, the number of possibilities of exemption from reimbursement of damages caused during professional activities decrease.

By growth of the number of corporate liability insurances, the risk group also increases, which may lead to the reduction of the insurance fees by the insurance companies. This may eventually increase the willingness for insurances.

By communicating the significance of the liability insurance, by the economic up-turn and by the change of the legal background, the level of insurance is expected to increase in the future. Market actors become more conscious and they turn their attention to the insurance companies, so that the demand of insurance increases on corporate side.

The development of the corporate liability insurance market in Hungary and the higher level of the insurance culture therefore necessitates the realization of harmonized and complex tasks. Beside the regulatory side these tasks appear on the market and customer side as well. The progress experienced on the market so far, the regulatory changes and the demand of a more conscious operation by the entrepreneurs indicate altogether a positive prospect.

\section{References}

1. HVG.HU (2012): Vörösiszap katasztrófa: két éve bankban fekszik az adományozók pénze. hvg.hu, 2012. október 06.

http://hvg.hu/itthon/20121006_karmento_alap_penz_vorosiszap_lekot

2. Illés B. Cs., Márki J. (2000): A hazai biztosítási intézményrendszer problémái és fejlesztésének lehetőségei. pp. 176-191. In: Molnár et al. (eds) Vision-2000/II. Az intézményi rendszer helyzete és fejlesztése az agrárgazdaságban, az EU csatlakozás tükrében. Szent István Egyetemi Kiadó, Gödöllő

3. Illés B. Cs., Megyeri G. (2010): Biztosítási ismeretek. Szent István Egyetemi Kiadó. 202 p.

4. IPCC (2014): http://ar5-syr.ipcc.ch/topic_futurechanges.php; retrived December 2015 
5. Kovács I. T., Nagy Cs. I. (2011): Szakmai felelősségbiztosítások piacának sajátosságai Magyarországon. A Gazdasági Versenyhivatal versenykultúra központjának GVH VKK/2011. sz. pályázatának keretében, Biztosítási Oktatási Intézet, Budapest

6. MABISZ (2015): Vagyonbiztosítás 2014. évi adatszolgáltatás

7. MNB (2015): Az MNB által felügyelt szektorok adatainak idősorai - Biztosítási szektor; http://felugyelet.mnb.hu/data/cms762375/idosor_biztosito_2015.I.ne.xls; 2015-04-30

8. Nagy P., Micski J. (2012): A szakmai felelősségbiztosítások piacának sajátosságai Magyarországon, GVH Versenykultúra Központ támogatásával, Infrapont Kft., április

9. Pandurics A., Markó O. (2015): A felelősségbiztosítás szerepe, jelene és jövője Magyarországon, Biztosítás és Kockázat, II. évfolyam 3. szám

10. Ptk. (2013): 2013. évi V. törvény a Polgári Törvénykönyvről, Harmadik könyv, I. rész, III. cím VI. fejezet $(3: 24 \S)$

11. Rejda G. E., McNamara M. J. (2014): Principles of Risk Management and Insurance, 12th Edition, Pearson pp. 582-592

12. Swiss Re (2009): Commercial liability: a challenge for businesses and their insurers, Sigma, 2009/5

13. Swiss Re (2014): Liability claim trends: emerging risks and rebounding economic drivers, Sigma, 2014/4

14. Trieschmann J. S., Hoyt R., Sommer D. (2005): Risk Management and Insurance, 12th Edition, Thomson-South Western

15. 1996. évi LV. tv. a vad védelméről, a vadgazdálkodásról, valamint a vadászatról.

16. 1997. évi CLIV. tv. az egészségügyről.

17. 49./2004. VIII. 31. BM rendelet a lőterekről, a lőfegyverek, lőszerek hatósági tárolásáról, a fegyvertartáshoz szükséges elméleti és jártassági követelményekröl.

18. 7/2011. X.24. MÜK (Magyar Ügyvédi Kamara) Szabályzat az ügyvédi felelösségbiztosítás legalacsonyabb összegéröl.

19. 2012. évi CXXVII. tv. a Magyar Állatorvosi Kamaráról, valamint az állatorvosi szolgáltatói tevékenység végzéséről. 